\title{
The Effectiveness of the Use of Nurse Safety Booklet on Nurse Knowledge in Ergonomic Injury Prevention in BIMA Hospital
}

\author{
A. Haris $^{1} \&$ Abdul Haris ${ }^{1}$ \\ ${ }^{1}$ Nursing Departement, Poltekkes Kemenkes Mataram, West Nusa Tenggara, Indonesia \\ Correspondence: A. Haris \& Abdul Haris, Nursing Departement, Poltekkes Kemenkes Mataram, West Nusa \\ Tenggara, Indonesia.
}

Received: May 13, 2019

Accepted: June 10, 2019

Online Published: June 13, 2019

doi:10.20849/ijsn.v4i2.578

URL: https://doi.org/10.20849/ijsn.v4i2.578

\begin{abstract}
Safety has become a global issue in various sectors, including the health services sector. The hospital is one of the health service organizations that is guided to continuously improve quality by building safer and safer health services so as to get customer loyalty. Hospital staff is a major component of quality management in one of the indicators in evaluating hospital accreditation. This research uses a quasi-experimental research design pre and posttest with control group. Quasi experiment research is a study that tests an intervention in a group of research subjects and then measures the results of the intervention. Samples in this study are all nurses who are in the room of the General Hospital, Surgery and ICU Bima Hospital, which are 50 people. The results showed the results of different tests using paired t-test $p$ value $=0.000$ which can be concluded that there are differences between the intervention group and the control group, seen from the value of the difference in the intervention group is greater than the difference in the control group can be interpreted as education using more booklets affect the increase in nurse knowledge. The conclusion in this study was that there were significant differences in nurses' knowledge after being given education using pre and post intervention booklets between the intervention and control groups $(\mathrm{p}=0.000)$.
\end{abstract}

Keywords: knowledge of nurse, ergonomic injury

\section{Pendahuluan}

Safety has become a global issue in various sectors, including the health services sector. The hospital is one of the health service organizations that are guided to continuously improve quality by building safer and safer health services so as to get customer loyalty. Hospital safety is a major component of quality management in one of the indicators in evaluating hospital accreditation.

The focus of the hospital today is patient safety, but the safety of hospital staff is equally important. Goodmn (2004) suggests that patient safety, officer safety, and system safety are interrelated and related to each other. Nurses are the most trusted patients with the composition of almost $60 \%$ of all health workers in the hospital and make the longest contact with patients. Good knowledge of safety among nurses will have a significant impact on the quality of health services at the hospital. A hospital is a place that poses a danger to nurses. Nurses can experience various types of injuries and illness risks while working. Health workers are at high risk of having work-related accidents and contracting work-related diseases compared to other workers. The nurse experienced an injury incidence of 8.8 times per 100 employees in the hospital and 13.5 per 100 employees in the nursing home. Occurrence and work-related accidents in nurses can be caused by unsafe environmental factors, which can also be caused by a lack of insecure knowledge and behavior. Heinrich stated that $88 \%$ of accidents at work were caused by unsafe behavior. Silalahi said that $64.26 \%$ of work-related illnesses and work-related accidents were caused by low knowledge, understanding, and awareness of occupational safety and health. Sumakmur said $85 \%$ of the causes of work-related illnesses and work-related accidents stemmed from human factors. The behavior and knowledge of the health and safety of the nurse's work in the hospital are very important because even the slightest risk will arise for nurses and patients.

Knowledge and attitudes of nurses related to the dangers faced by nurses while working in hospitals and how to prevent their handling of nurses' health and safety behavior. The risk of danger in hospitals is biological, scales, chemical, ergonomic and psychosocial hazards. Nurses can experience ergonomic cervix that is serious due to lifting or moving the patient. Nurses have the greatest risk of experiencing low back pain (LBP) and 
musculoskeletal injuries at the hospital (The prevalence of nurses experiences LBP $40-50 \%$ per year and 35-80\% throughout life with very high health claims. In 2001 in the United States, 108,000 registered nurses experienced work-related musculoskeletal problems, which are the same as building construction workers (Trinkoff, 2008). More than one third of nurses have suffered severe back injury which causes nurses to have to leave work (Zerwekh \& Claborn, 2009).

The nurse needs safety at work. Salvation is one of the basic human needs that must be fulfilled. Humans need long life and wherever they are meant at work. The organization is fully responsible for providing a safe environment that supports nurses to be safe in their work. Indonesian's Law concerning accident prevention safety explains that companies must protect workers' safety by providing explanations to workers about the conditions and dangers of proper work, personal protective equipment, which is carried out in workplaces, personal protective equipment for workers and safe ways and attitudes in carrying out work.

Nurses often care less about the dangers in the workplace and in carrying out self-protection efforts even though the nurse knows that this can endanger the health and life of the nurse. Knowledge of nurse safety is a very important factor in preventing the exposure of nurses to the dangers of injury and disease in the workplace (Trinkkoff, 2007). Knowledge is needed as an impulse that stimulates one's actions so that behavior will be permanent. Nurse safety knowledge includes the introduction of the hazard risks faced by nurses at the hospital as well as ways to prevent and treat them (Ramsay, 2005).

The behavior of nurses in work is guided by work guidelines. Procedures and work guidelines are a component of planning in the management of compliance. In addition to standard operational procedures (SOP) and nursing care standards as guidelines for nurses at work, guidance on the safety of nurses is needed to guide nurses to behave safely and safely at work. The use of nurse safety guidelines needs to be tested for their influence on improving health and safety behavior of nurses in work, so that if they can effectively reduce the incidence of occupational diseases and accidents due to work to nurses.

Until now there has not been much research on nurse health and safety in Indonesia. Afifka, 2003 states that occupational health and safety programs have a positive influence on increasing employee work productivity because they form knowledge, skills, and good attitudes towards occupational health and safety so as to prevent or reduce work-related losses and work-related accidents. Research related to the effectiveness of education by using nurse safety booklets on nurse knowledge and preventing ergonomic injuries has not been done. Based on the above phenomena, researchers are interested in investigating the effectiveness of education by using nurse safety booklets on nurse knowledge in preventing the occurrence of ergonomic injury prevention.

\section{Method}

This study used a quasi-experiment design pre and post-test with the control group. The population in this study was an executive nurse who worked in the IGD Room of Bima Hospital. The number of samples is 50 people. The sampling method in this study is total sampling. The total sample is a sampling technique in which the number of samples is with the population. Inclusion Criteria: Nurses who are in service in the room and are willing to be respondents. Exclusion Criteria: Head of the room. Data Collection Tool in the form of Instrument A in the form of a questionnaire regarding the characteristics of nurses. Nurse characteristic data is primary data that is made by the researcher itself and consists of variables of age, sex, education and years of service and Instrument $\mathrm{B}$ in the form of a questionnaire containing questions based on the material in the nurse safety booklet totaling 10 questions for each answer value 1 and wrong answer worth 0 . Questionnaire validity has been applied to 5 nurses who were not respondents in this study. In this study, data analysis was carried out using a computerized program through the following stages: Univariate analysis to see the description of the characteristics of respondents based on nurses' age and sex. Bivariate analysis was carried out to identify the effectiveness of two variables, namely education using a booklet on knowledge of care to prevent the occurrence of ergonomic injuries. The statistical test used was the Paired t-test.

\section{Discussion}

Table 1. Characteristics of respondents based on age

\begin{tabular}{lllll}
\hline Age & Intervention & \multicolumn{3}{l}{ Control } \\
\hline & $\mathrm{N}$ & $\%$ & $\mathrm{~N}$ & $\%$ \\
\hline $17-25$ & 1 & 5.6 & 5 & 27.8 \\
\hline
\end{tabular}




\begin{tabular}{lllll}
\hline $26-35$ & 6 & 33.4 & 0 & 0 \\
\hline $36-45$ & 18 & 61.1 & 20 & 72.3 \\
\hline
\end{tabular}

Table 1 shows that the respondents in the most intervention group were 36-45 years as many as 18 people (61.1\%), the control group was the most aged $36-45$ years as many as 20 people $(72.3 \%)$.

Table 2. Characteristics of respondents by gender

\begin{tabular}{lllll}
\hline Variable & Intervention & \multicolumn{3}{l}{ Control } \\
\hline & $\mathrm{N}$ & $\%$ & $\mathrm{~N}$ & $\%$ \\
\hline Male & 7 & 27.8 & 7 & 27.8 \\
\hline Female & 18 & 72.2 & 18 & 72.2 \\
\hline
\end{tabular}

Table 3. Characteristics of respondents by education level

\begin{tabular}{lllll}
\hline Variable & \multicolumn{2}{l}{ Intervention } & \multicolumn{2}{l}{ Control } \\
\hline & $\mathrm{N}$ & $\%$ & $\mathrm{~N}$ & $\%$ \\
\hline Diploma III & 15 & 50.0 & 17 & 55.6 \\
\hline Diploma IV & 3 & 11.1 & 1 & 5.6 \\
\hline Bachelor & 7 & 38.9 & 7 & 38.9 \\
\hline
\end{tabular}

Table 4. Distribution knowledge of nurse

\begin{tabular}{|c|c|c|c|c|c|c|c|c|c|c|c|c|c|}
\hline \multirow[t]{3}{*}{ Variable } & \multicolumn{7}{|c|}{ Control } & \multicolumn{6}{|c|}{ Intervention } \\
\hline & \multicolumn{2}{|c|}{ Pre } & \multicolumn{2}{|c|}{ Post 1} & \multicolumn{2}{|c|}{ Post 2} & Post 3 & \multicolumn{2}{|l|}{ Pre } & \multicolumn{2}{|c|}{ Post 1} & Post 2 & Post 3 \\
\hline & $\mathrm{n}$ & $\%$ & $\mathrm{n}$ & $\%$ & $\mathrm{~N}$ & $\%$ & n $\quad \%$ & $\mathrm{n}$ & $\%$ & $\mathrm{n}$ & $\%$ & $\%$ & $\%$ \\
\hline Mean & \multicolumn{2}{|c|}{$4.61 \pm 1.378$} & \multicolumn{2}{|c|}{$6.83 \pm 0.924$} & \multicolumn{2}{|c|}{$7.89 \pm 1.023$} & $8.39 \pm .608$ & \multicolumn{2}{|c|}{$4.83 \pm 0.707$} & \multicolumn{2}{|c|}{$7.56 \pm 1.504$} & $8.44=0.856$ & $9.89 \pm 0.323$ \\
\hline High & 0 & & 20 & 72.2 & 25 & 100 & 100 & & & 18 & 72.2 & 100 & $25 \quad 100$ \\
\hline Moderate & 18 & 61.1 & 5 & 27.8 & & & & 25 & 100 & 7 & 27.8 & & \\
\hline Low & 7 & 38.9 & & & & & & & & & & & \\
\hline
\end{tabular}

Table 5. Differences in mean knowledge of nurses in the control group and intervention group before and after intervention

\begin{tabular}{lllll}
\hline Group & $\mathrm{N}$ & Mean & $\mathrm{SD}$ & $\mathrm{P}$ \\
\hline Intervention & & & & \\
\hline Pre - Post test days-3 & 25 & -5.056 & 1.680 & 0,00 \\
\hline Pre - Post test days-1 & 25 & -2.722 & 0.351 & 0,00 \\
\hline Pre - Post test days-2 & 25 & -3.611 & 1.037 & 0,00 \\
\hline Post 2- Post -3 & 18 & -1.444 & 0.856 & 0,00 \\
\hline Control & & & & \\
\hline Pre - Post test days-3 & 25 & -3.778 & 1.437 & 0,00 \\
\hline Pre - Post test days-1 & 25 & -2.222 & 1.263 & 0,00 \\
\hline Pre - Post test days-2 & 25 & -3.278 & 1.602 & 0,00 \\
\hline Post 2- Post -3 & 25 & -0.500 & 0.924 & 0,35 \\
\hline
\end{tabular}


Table 5 shows that after being given an intervention using a booklet can increase nurse knowledge by $104.76 \%$, as well as in the Control group after being given education can increase nurses' knowledge by $81.49 \%$. The results of different tests using paired t-test $p$-value $=0.000$ which can be concluded that there are differences between the intervention group and the control group, seen from the value of the difference in the intervention group greater than the difference in the control group can be interpreted that education using booklets has more influence on the increase in nurse knowledge.

All ages in the respondents in the study were the highest intervention group, namely $36-45$ years old as many as 18 people $(61.1 \%)$, the control group was the most aged 36-45 years as many as 20 people $(72.3 \%)$. In accordance with what Cuwin (2009) stated that adulthood (18-40 years) is a period in which a person can reach a maximum achievement in his career. Hopefully, with more age, the level of maturity and strength of someone will be more mature to think and work.(Hedge, James, \& Pavlovic-Veselinovic, 2011)

In terms of public trust, an adult is more trusted than someone who is not yet mature. While according to the factors that influence the knowledge of one's fault are age. The more mature the level of maturity and strength of a person will be more mature in thinking and working in terms of trust in a more mature community will be more trusting than people who are not high enough maturity. Judging from the education level of the respondents in the intervention group, the D3 education level was 15 people (50.0\%) and the respondents in the education level control group were D3 of 17 people (55.6\%).(Trinkoff et al., 2008)

Decree of the Minister of Health in Indonesia number 1239 of 2001 states that the minimum standard of nurse education at health care institutions is Diploma III nursing (Ministry of Health Indonesia, 2001). As stated by Soeroso (2003) that more than $60 \%$ of nurses still have Diploma III education in Indonesia. Based on the results of the study, the majority of the sexes in the most intervention group were women as many as 18 people (72.2\%) and in the control group the same sex was the most women were 18 people $(72.2 \%)$. The results of this study have similarities with other studies entitled The relationship of knowledge and attitudes of nurses to the implementation of patient safety obtained by the results of female studies as much as $95.4 \%$. This is consistent with Kozier \& Erb's (2005) opinion of the mother's instinct philosophy that the majority of nurses come from women, where a woman has an instinct to care for herself as reflected in a mother and simple instincts in maintaining family health, especially children (Fragala, 2002).

The results of the study that identified nurses' knowledge in the control group and the intervention group showed that in the control group before being given education on nurses' knowledge insufficient categories, there were 18 people (61.1), then in the 1st post-test after being educated there was an increase in nurses' knowledge the good knowledge category was 20 people $(72.2 \%)$, while in the second and third post-tests there was an increase in knowledge of 5 people to 25 people (100). In the intervention group before being given education using a booklet, there were 25 nurses in the adequate category (100), in the first post-test after giving intervention there was an increase in knowledge in 18 categories of good knowledge (72.2) and in the post-test second and third there was an increase in nurses' knowledge by 25 people (100) in the good knowledge category. Knowledge of nurses about the knowledge of ergonomic injuries is expected to be the basis for conducting nursing care to patients at risk of injury.(Rothmore, Aylward, \& Karnon, 2014)

The results of this study have similarities with other studies that illustrate the level of knowledge of stroke risk factors, respondents are more in the good category that is equal to $78.9 \%$. The more information that comes in the more knowledge is gained (Trinkoff et al., 2008)

The results of the analysis after being given an intervention using a booklet can increase nurse knowledge by $104.76 \%$, as well as in the group after being given education can increase nurse knowledge by $81.49 \%$. Adjust the theory put forward that the knowledge aspect is a very important dominant for the formation of behavior. A person will be able to influence the mindset and attitude towards something, that is, with good knowledge, it will adhere to standard operating procedures to reduce the risk of injury. States those effective health education methods have an effect on increasing self-efficacy. Methods and information delivery media can have a significant effect on self-efficacy. The media used by researchers in providing health education is in the form of powerpoint slides where the media clarifies the message the researcher wants to convey. (Puspasari, 2014)

After passing health education, the researcher gave a demonstration where it was one of the methods used to increase one's knowledge and abilities through learning techniques or instructions in order to practice what was given by the researcher, and after completion researchers provided leaflets for follow-up plans so that respondents can recall what was given by the researcher. Thus, nurses and midwives are better able to understand and understand the care of the kangaroo method.(Rogers, Buckheit, \& Ostendorf, 2013) 
The results of the analysis in the Control group after being given education could increase nurses 'knowledge by $81.49 \%$. As for other studies stated that there was an influence between knowledge and nurses' compliance in the implementation of urethral installation and drainage in Sinjai District Hospital. Here it is stated that with good knowledge will give someone's impulse to obey, this is because with good knowledge, someone or respondent has the ability to synthesize and evaluate in answering the questionnaire given (Cheung, Feletto, Galante, \& Waters, 2007)

\section{Conclusion}

The description of nurses' knowledge tended to experience an increase in both the intervention group and the control group, but the intervention group had a greater decrease than the control group as many as 18 people $(100 \%)$. There was a significant difference in nurses' knowledge after being given education using pre and post booklets interventions between intervention and control groups $(\mathrm{p}=0.000)$

\section{References}

Cheung, Z. (Cal/OSHA C. S.), Feletto, M. (Cal/OSHA C. S.), Galante, J. (EASE C.), \& Waters, T. (NIOSH). (2007). Ergonomic guidelines for manual material handling. DHHS (NIOSH) Publication, 131. https://doi.org/10.1017/CBO9781107415324.004

Fragala, G. (2002). Ergonomics and injury prevention in healthcare. Director (Cincinnati, Ohio), 10(2), 51,53-54 Retrieved from http://www.embase.com/search/results?subaction=viewrecord\&from=export\&id=L40264188\%5Cnhttp://sf x.aub.aau.dk/sfxaub?sid=EMBASE\&issn=15518418\&id=doi:\&atitle=Ergonomics + and + injury + prevention + in + healthcare. $\&$ stitle $=$ Director\&title $=$ Director $\% 28$ Cincinnati $\% 2 C+O h i o \% 29$

Hedge, A., James, T., \& Pavlovic-Veselinovic, S. (2011). Ergonomics concerns and the impact of healthcare information technology. International Journal of Industrial Ergonomics, 41(4), 345-351. https://doi.org/10.1016/j.ergon.2011.02.002

Puspasari, S. (2014, April). Ergonomics of nurse knowledge.

Rogers, B., Buckheit, K., \& Ostendorf, J. (2013). Ergonomics and nursing in hospital environments. Workplace Health \& Safety, 61(10), 429-439. https://doi.org/10.1177/216507991306101003

Rothmore, P., Aylward, P., \& Karnon, J. (2014). Ergonomics and musculoskeletal injury prevention interventions in healthcare : Are they worth it?. Human Factors \& Ergonomics Society of ustralia Inc, 8(1), $1-5$.

Trinkoff, A. M., Geiger-Brown, J. M., Caruso, C. C., Lipscomb, J. A., Johantgen, M., Nelson, A. L., ... Selby, V. L. (2008). Personal Safety for Nurses. Patient Safety and Quality: An Evidence-Based Handbook for Nurses. Retrieved from ttp://www.ncbi.nlm.nih.gov/pubmed/21328762

\section{Copyrights}

Copyright for this article is retained by the author(s), with first publication rights granted to the journal.

This is an open-access article distributed under the terms and conditions of the Creative Commons Attribution license (http://creativecommons.org/licenses/by/4.0/). 